\title{
Review of pallet pooling studies
}

\author{
Chunhua CHEN 1,2, J ianwei Ren 3,4,5* and Yunga A 2 \\ $1 \mathrm{~J}$ iangxi University of Finance and Ec onomics / School of Business Administration, Nanchang, China \\ 2 Agric ultura I Bank of China / Inner Mongolia Branch, Hohhot, China \\ 3 Inner Mongolia University / Transportation Institute, Hohhot, China \\ ${ }^{4}$ Inner Mong olia University / School of Mathematical Sciences, Hohhot, China \\ 5 University of Plymouth / Faculty of Business, Plymouth, United Kingdom
}

[Corresponding Author indic a ted by an asterisk *]

\begin{abstract}
Development of sharing economy has brought new opportunities to the development of green logistics. Pallet pooling is a typical type of sharing economy. It has been recently promoted in almost every country in the world. Researchers have reached a common agreement that establishing an effective pallet pool is of great importance to the pallets use efficiency. It is also believed that the implementation of pallet pool will substantially contribute to the economic and social development Detailed analysis of pallet pooling such as benefit analysis, mode choose, pallet allocation model \& algonithm, quality control, etc. are disc ussed in this paper. Based on literature review, several important problems are listed for future study. These problems are information management, supply chain management, rental pricing, pallets tracking and allocation, quality control, sustainable development (carbon emissions), and "intemet plus pallet pooling". Some suggestions on China's pallet pooling development are proposed as well.
\end{abstract}

Key words-logistics, pallet pool, rental, intemet plus, China.

\section{INTRODUCTION}

The sharing economy has gained an inc reasing popularity. There a re several excellent companies specia lizing in this field such a s Uber a nd Airbnb. It's commonly believed that Uber is a transportation network company and Airbnb is a company providing online marketplace and hospitality service. The research report of PWC2015 shows that the market value of sharing economy has been estimated more than 335 billion dolla rs by 2025. China's govemment work report in 2016 also pointed out that they would support the development of sharing economy. In fact, applying sharing economy concept in logistics field is never a new idea. In 1945, CHEP (Commonwealth Handling and Equipment Pool) had a lready been providing a pallet rent service in Australia after the Second World Warwhich is regarded as a form of Pallet pooling in sharing economy area.

Pallets are nowadays broadly used over the world. It is one of the two key innovations in the logistic sindustry in 20th Century [1]. A pallet pool is a pool in which there are many pallets. Users of the pool could use these pallets. This pool could be established by a pallet rental company or some cooperative partners. By the method of pallet pooling, pallets in the pool can be more efficiently utilized [2]. Cargos from the seller to their buyer's destination in a sup ply cha in are nomally delivered on pallets. Without a pallet pool, they have to be unloaded from their pallets after reaching the destination because those pallets belong to the seller and others are not allowed to use them [3].

Since 1945, the users of pallet pooling have witnessed a rapid development in Australia, United States, Japan, etc. to the contrary that the booming of it in China has been reckoned no more than 10 years (Although China's railway department tried to promote pallet pooling in 1965, they failed). Recently, related researchers in China are glad to see that the Chinese govemment is paying highly attention to pallet pooling and has exerted considerable influence on the establishment and subsequent promotion and utilization of it. In "The plan of logistics industry restructuring and revita liza tion" and "The long-term plan of logistic industry development (2014 - 2020)", pallet pooling is pointed out as an important innovative technology of the logistic sindustry therefore it should be propelled as soon as possible. The govemment of Beijing, Shanghai, Guangdong, Inner Mongolia and other provinces, munic ipalities and autonomous regions also have confimed that the pallet pooling is a significant method for logistics industry's development. In recent years, some representative pallet pools are built up and put into use in China such as China Merchants Loscam pallet pool, China pack J ingli pallet pool, Shandong Libao pallet pool, and so on.

Since 1960s, scholars in UK, USA, and Australia had already begun to study pallet pooling, while Chinese scholars started from 2003. In 2001, a paper published on "Joumal of Logistics Technology 
and Application". It was the China's first paper focusing on pallet pooling, but its a uthor is J apanese [4]. Wu [5] is reckoned as the first Chinese scholar doing research on pallet pool. Given the fact that there are many literatures on it, we still can't find an overall literature review on the research of pallet pooling. In this paper, the literature review on pallet pooling study will be presented in section 2. Several hot study fields in pallet pooling are given in section 3. Some suggestions on the development of pallet pooling in China are also proposed in section 3 . Conclusions are made in section 4.

\section{REVIEW}

As shown in Figure 1 6, pallets can be used in several different ways. Pallets can be categorized into three types by their usage scenarios. We define them as purchased pallets and rent pallets by their ownership. We define them as disposable pallets and reusable pallets based on whether they can be reused or not. We define them as static pallets (those a re only used in one enterprise) and dynamic pallets (those a re used in a supply cha in) based on whether they are used only in a certain company or in a whole supply chain.

Pallets in pallet pooling are a combination of dynamic pallet and reusable pallet. They either belong to a rental company (like the CHEP pallet pool and Loscam pallet pool) or a nomal company (like the United States postal pallet pool). Pallet pooling is a mode regarded as the most effective pallet management mode. Scholars have paid great effort to study this potential and beneficial mode. Literatures on pallet pooling mostly are focused on benefit analysis, mode choose, supply chain and information management, pallet allocation model and algorithm, rental pricing, quality control, susta ina ble development (carbon emissions), etc.

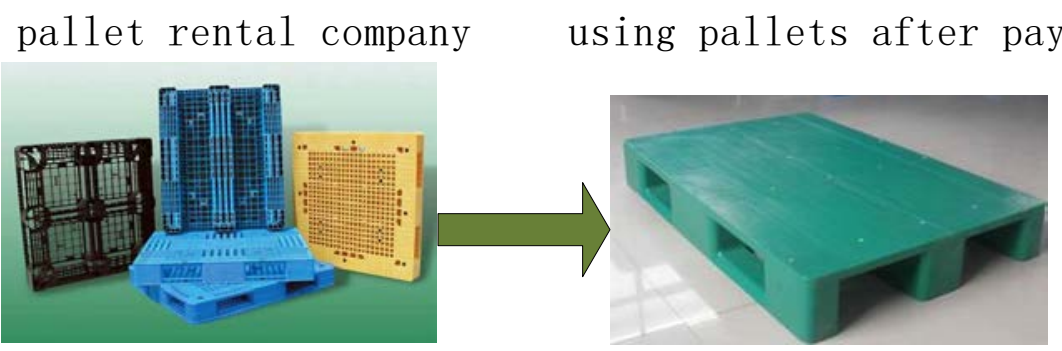

Figure 1. Rent

pallet manufacture purchase pallets

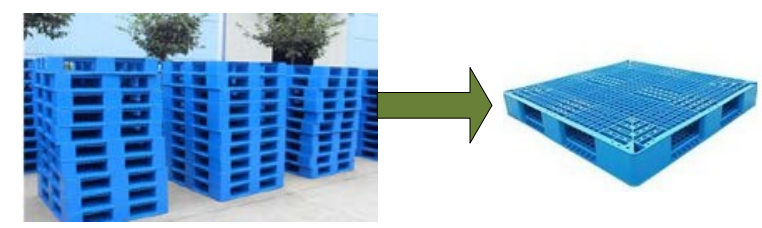

Figure 2. Purchase
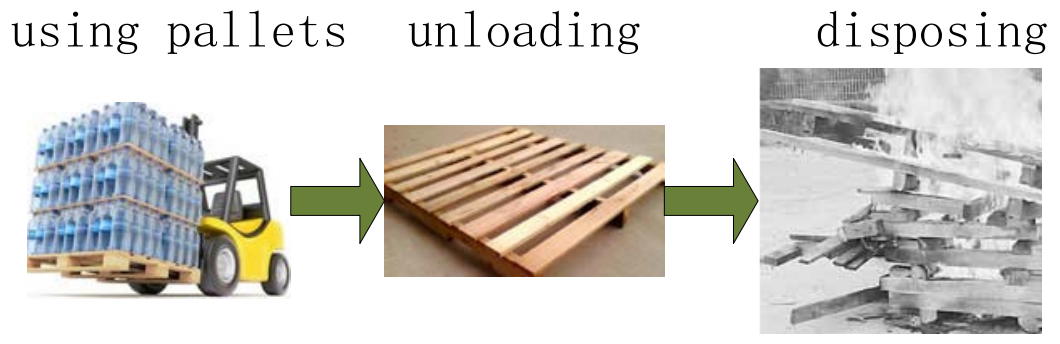

Figure 3. Disposing 
using pallets unloading reusing

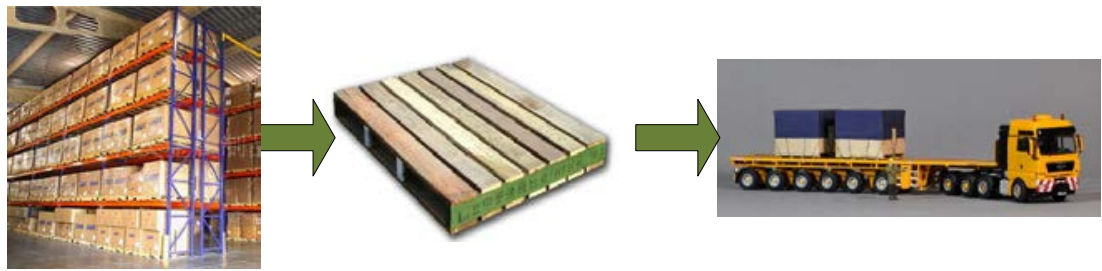

Figure 4. Reusing

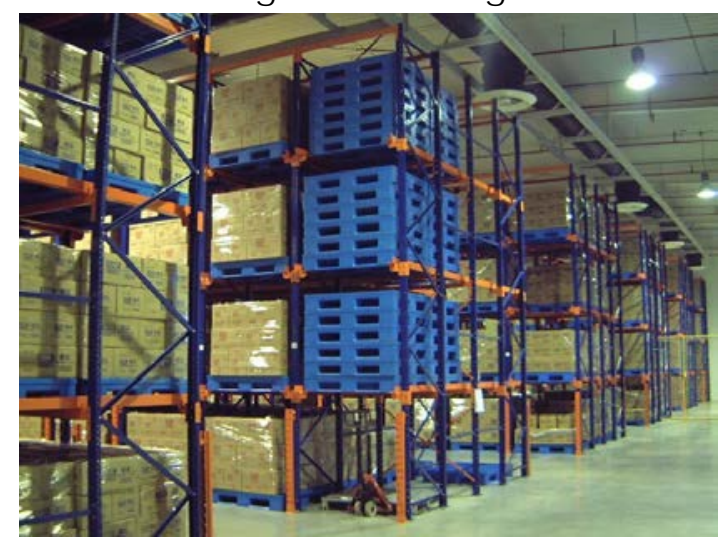

Figure 5. Static

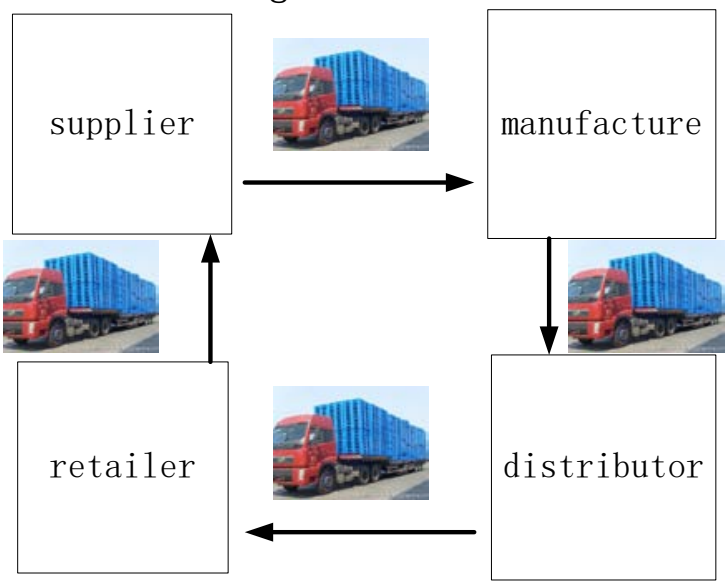

Figure 6. Dynamic

\section{A. Benefits of pallet pooling}

The economic and social benefits of pallet pooling are signific ant. Sakai [6] pointed out that the development of pallet pooling was beneficial to both enterprises and society. Auguston [7] stated that the development of pallet pooling in the United States was not good enough. That's one of the rea sons why the logistics costs were still high. Don [8] proposed that pallet pooling is not only able to help companies save costs, but can also enhance the efficiency of warehousing and transportation. According to the study on CHEP, Witt [9] proved that pallet pooling was an exc ellent way to save costs. Raballand \& Carroll [10] also pointed out that companies using pallet pooling had reduced their operating costs. Wu [5], Meng \& Sun [11], and Li [12] proposed that the development of pallet pooling was of great signific ance to China. A pallet pool in Sweden simplified the process of transporting goods from Sweden to the UK [13]. Ray's research shows that the PLUS (Pallet loading and unloading system) essential to the United States [14]. Brindley [15-16] studied Chinese pallet pooling development and found that the potential market of Chinese pallet pooling was enormous.

However, according to the research of Ray et al. [17], a company will cost more if it rents pallets instead of purchasing. Roy et al. [18] proposed a two stage model to compare the cost of using single-use expendable pallets and rental pallets. They found that the cost of single-use expendable pallets is even lower than renting pallets. Lacefield [19] and Mosqueda [20] advised that a company 
choose rental pallets or purchase pallets should be based on its actual situation in the belief that pallet pooling is not always the right choice for every enterprise. This idea can expla in why Ray's conclusion is different from others.

More and more companies a re using pallet pool is the best indirect proof that using pallet pooling provides great advantages. In 2014, Michel [21] made an investigation in the United States. He found that $57 \%$ of companies surveyed wanted to use pallet pooling services. This figure is $13 \%$ higher than that of 2013.

\section{B. Pallet pooling modes}

The traditional study on pallet holds that the modes of pallet pooling include rent, exchanging, and rent $\&$ exchanging. But Ha mis and Worrell [2] pointed that there were basically three methods of pallet management including transfer of ownership, pallet exchange, and pallet pooling. According to their study, there are three types of pallet pool which are third party owned pool, third party management pool and private pallet pool. In the third party owned pool which is also called pallet rent pool, pallets belong to a pallet rental company and the company's customers can use these pallets. In the third party management pool and the private pool, pallets belong to a specific company and they cannot be used by others except that company. These two types of pallet pools are actually not real pallet pools. We can therefore come to a conclusion that the basic modes of pallet pooling including transfer of ownership, rent, and exchanging. A company is free to use more than one mode, according to its needs, to build up its own pallet pools, such as rent \& exchanging, transfer \& rent, transfer \& exchanging, transfer \& exchanging \& rent. Three basic pallet pooling modes are shown in table 1.

Despite that each kind of pallet pooling mode has its advantages and disadvantages, the rent \& exchanging mode is world widely gaining greater popularity than the transfer of ownership mode. In fact, rent $\&$ exchanging mode is the most frequently used mode in many countries. England is the first country which implemented the rent \& exchanging mode. L [12] and Lai [22] suggested that it was necessary to develop rent \& exchanging mode of pallet pool in China. Yu [23] also advised that rent \& exchanging mode of railway pallet pool should be adapted in China. However, Wang \& Gu [24] holds that using rent mode of pallet pool is able to meet all the needs in China. J in et al. [25] and Ge [26] suggested the Chinese govemment develop a new pallet pool taking commercial bank as reference. They named this kind of pool as pallet bank. The customers of the pallet bank can rent from the pallet bank. The branches of a pallet bank can exchange their pallets. It's not hard to notice, based on their mode, that the essence of pallet bank is still the rent $\&$ exchanging mode of pallet pooling.

Table 1. Three basic pallet pooling modes

\begin{tabular}{|c|c|c|c|}
\hline Items & Rent & Exchanging & Transfer of ownership \\
\hline Partic ipants & $\begin{array}{c}\text { Pallet rental company } \\
\text { and its customers }\end{array}$ & $\begin{array}{c}\text { Companiesin a pallet } \\
\text { pool }\end{array}$ & $\begin{array}{c}\text { Companies in a pallet } \\
\text { pool }\end{array}$ \\
\hline $\begin{array}{l}\text { Operational } \\
\text { processes }\end{array}$ & $\begin{array}{c}\text { A pallet rental company } \\
\text { provides pallets a s well as } \\
\text { some servic es to its } \\
\text { customers whic h a re } \\
\text { rec ycling and } \\
\text { ma intenance of pallets. } \\
\text { Its customers do not need } \\
\text { to buy pallets. They use } \\
\text { pallets to tra nsp ort their } \\
\text { cargos after the rental } \\
\text { fee is paid. }\end{array}$ & $\begin{array}{l}\text { Companies are } \\
\text { supposed to provide the } \\
\text { same amount of empty } \\
\text { pallets which is equal to } \\
\text { that of pallets received } \\
\text { a lone with cargos to their } \\
\text { suppliers. Likewise, their } \\
\text { customers have to do } \\
\text { the same to them. }\end{array}$ & $\begin{array}{l}\text { Companies have to buy } \\
\text { the pallets from their } \\
\text { suppliers when cargos } \\
\text { are purchased before } \\
\text { transportation. Likewise, } \\
\text { their customers have to } \\
\text { do the same to them. }\end{array}$ \\
\hline Advantages & $\begin{array}{l}\text { The pallet pool is } \\
\text { managed by a } \\
\text { professional rental } \\
\text { company. Customers } \\
\text { can signific antly reduce } \\
\text { their logistic scost. }\end{array}$ & $\begin{array}{l}\text { Small investment; } \\
\text { Simple operation. }\end{array}$ & $\begin{array}{l}\text { Small investment; } \\
\text { Simple operation. }\end{array}$ \\
\hline Disa dva nta ges & $\begin{array}{l}\text { Large investment; } \\
\text { Hard to operate. }\end{array}$ & $\begin{array}{l}\text { Some companies may } \\
\text { provide ill-conditioned }\end{array}$ & $\begin{array}{l}\text { Some companies do } \\
\text { not want to buy their }\end{array}$ \\
\hline
\end{tabular}




\section{Pallet pool supply cha in and information management}

As pallets are moving through the whole supply chain, it is important to manage supply cha in and information efficiently. Elia \& Gnoni [27] designed a closed-loop pallet pool supply chain, which consists of pallet suppliers, pallet recyclers, and upstream and downstream customers. Xu [28] studied on the method of pallet pool supply chain management and designed an information system based on RFID. Gnoni \& Rollo [29], Zhang et al. [30], and Kim \& Glock [31] studied on how to use RFID technology to track pallets. J in et al. [25] and Ge [26] designed two pallet pool management information systems based on RFID in order to manage pallet recycling and storage. Chen et al. [32] designed a pallet rental management information system based on RFID and B/S (Browser / server) mode. Zha o [33] proposed an information service framework for pallet pool supply chain management based on XML (QR). Li et al. [34] proposed a pallet pooling information platform using cloud computing. He also studied on the problem of XML data shaning, data link and bidirectional mapping rules. Although there are some literatures on pallet pool supply chain management and its information system, it is not adequate to meet the needs of the development of pallet pooling.

D. The methodology of pallet allocation over a pallet pool

How to allocate pallets over a pallet pool? This is a diffic ult problem. Ren et al. [35] proposed that, as shown in figure 7 , the whole process of pallet allocation includes purchase, rent, distribution, reposition, recycling, maintenance, and disposing. In each sub-process, pallets may be lost, destroyed, or ruined, etc. The whole process is so complicated that almost all of the managers of pallet pools in the world a re struggling to find an answer to how can we allocate pallets properly.

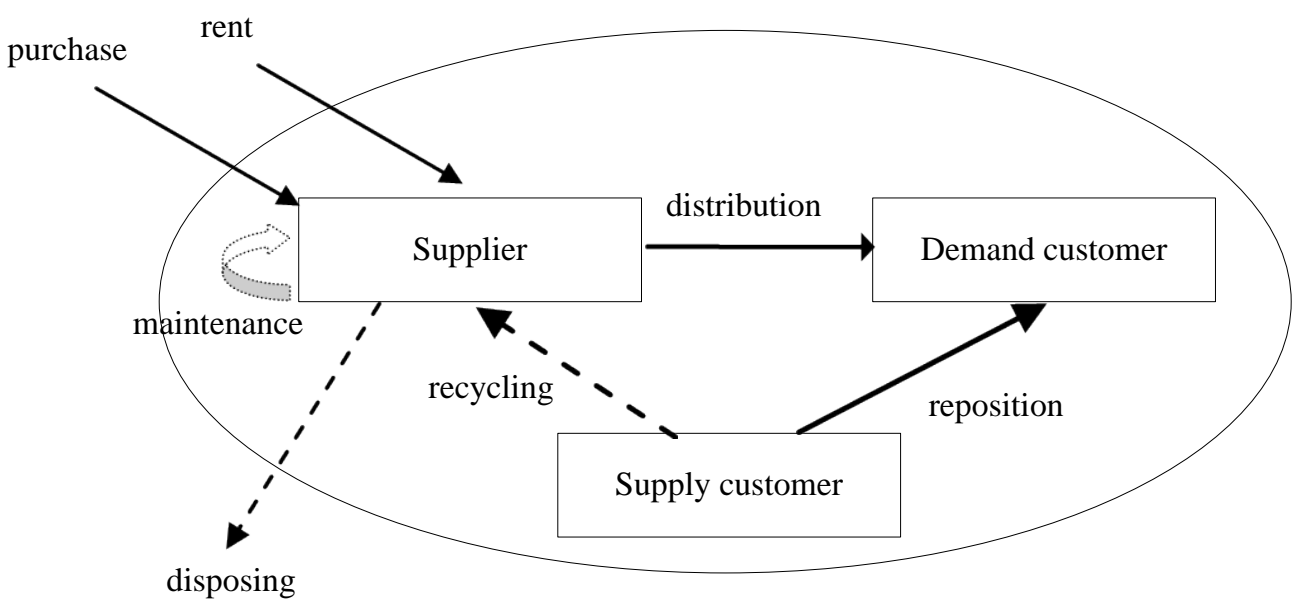

Figure 7. Pa llet alloc ation

Mosqueda [20] stated that if managers cannot effectively control the costs of pallet allocation, the successfully use of pallet pool was impossible. Brindley [36] studied on CHEP, iG PS and other pallet poolsand pointed out that pallet a llocation was not easy to every manager. Brindley [36] also said that the pallet damage rates of CPC and PECO were so high that extra attention should be paid to the pallet damage rate when managers allocate pallets. Besides, Doungpattra et al. [37] analyzed the methodology of how to reduce the transport pallet cost in pet food ind ustry. There are several scholars who also have done research on models and algorithms of pallet allocation (see table 2).

Table 2 Models and a lgorithms of pallet allocation over a pallet pool

\begin{tabular}{|c|c|c|c|c|c|c|c|c|c|c|}
\hline Literatures & Demand & Supply & $\begin{array}{c}\text { Stock } \\
\text { capacity }\end{array}$ & $\begin{array}{l}\text { Transportati } \\
\text { on capacity }\end{array}$ & $\begin{array}{l}\text { Loading and } \\
\text { unloading } \\
\text { capacity }\end{array}$ & Types & $\begin{array}{l}\text { Truck } \\
\text {-load }\end{array}$ & $\begin{array}{c}\text { Damage } \\
\text { rate }\end{array}$ & $\begin{array}{c}\text { Transportation } \\
\text { mode }\end{array}$ & $\begin{array}{l}\text { Solve } \\
\text { method }\end{array}$ \\
\hline Ren \& Zhang [38] & $\mathrm{D}$ & $\mathrm{S}$ & $D$ & $\mathrm{D}$ & - & ST & - & - & SM & Lingo \\
\hline Ren \& Zhang [39] & $\mathrm{D}$ & - & - & S & - & ST & - & - & SM & Lingo \\
\hline Ren \& Zhang [40] & $\mathrm{S}$ & $\mathrm{S}$ & $D$ & $\mathrm{~S}$ & S & ST & - & - & SM & Lingo \\
\hline Ren et al. [41] & $U$ & $U$ & $u$ & $U$ & U & MT & Y & $\mathrm{U}$ & SM & Lingo \\
\hline Zhou et al. [42] & D & $D$ & - & $D$ & - & MT & - & - & SM & Cplex \\
\hline
\end{tabular}




\begin{tabular}{|c|c|c|c|c|c|c|c|c|c|c|} 
Zhou et al. [43] & D & D & - & D & - & ST & - & - & MM & Cplex \\
\hline Zhou et al. [44] & S & D & - & - & D & ST & - & - & SM & ICA \\
\hline Ni et al. [45] & S & S & - & - & - & ST & - & - & SM & GA \\
\hline
\end{tabular}

D: deteministic; S: stochastic; U: uncertainty; ST: single-type; MT: multi-type; Y: pallets should be moved in truckload quantities; SM: single kind of transportation mode; MM: multi-type of transportation modes; ICA: immune clonal algorithm; GA: genetic algorithm

As shown above in table 2 , the pallet allocation models' objectives are all set to minimize the total cost. The constraints in those models include demand, supply, inventory capacity, transportation capacity, and loading \& unloading capacity. Most litera tures only researched on single type pallets. Literatures considering multi-type pallets are all based on an assumption that the demand of one type of pallets cannot be met by another one. Lingo and Cplex are the two mainly methods to solve those models. Immune clone algorithm and genetic algorithm are adapted in some papers. A basic pallet allocation model can be presented in a compact form.

$$
\begin{aligned}
& \min c x \\
& \text { s.t. } B x=b \\
& \quad x \in Z^{+} \cup\{0\}
\end{aligned}
$$

Equation (1) is to minimize the total pallet a llocation costs. The cost vector $c$ includes distribution, reposition, recycling, inventory, loading $\&$ unloading, rent, purchase, etc. The decision va riables are represented by $x$. Equation (2) represents all constraints (such as supply, demand, etc.). They are expressed as equalities by slack variables. Equation (3) is used to state that all decision variables should be non negative.

Pallet allocation is a brand new research field. There is very few literatures on it [46]. The literatures on the schedule problem, which has been studied since 1954 [47-48], are very helpful for the scholars who want to solve the problem of pallet allocation.

\section{E. Some other topics}

Although pallet pooling becomes more and more popular in the world and an increased number of literatures have been published, a lot of problems, such as the lost rate of pallets, pallet recycling, mea surement of carbon emissions in using pallet pool, pallet rent pricing, a re still in wait to be solved.

Baker [49] analyzed the HB 2168 regulations and thought the regulations would be helpful to reduce the lost rate of pallets. Bilbao et al. [50] proposed a linear programming model to compare the environmental impacts of various pallet management modes. Carrano et al. [51] proved that pallet pooling could reduce carbon emissions. Bengtssona \& Logiea [52] also proved that pallet pooling was the most environmentally friendly method in pallets management. Tomese et al. [53] showed that pallet remanufacturing could reduce carbon equivalent emissions up to $40 \%$. Tomese et al. [54] studied on the environmental impact of pallet pooling. China's standard pallets' specification is $1200 \mathrm{~mm} * 1000 \mathrm{~mm}$. Many scholars think that this kind of pallets is suitable to trucks and trains [55]. Xu [56] proposed a pricing model considering the influence of the lease tem and the retum rate, which could maximize the revenue of both the rental company and its customers. Wu et al. [57] gave a pallet rental pricing model based on the method of revenue management. Since the pallet pooling is very complex, a lot of problems a re worth studying by scholars.

\section{DISCUSSION}

\section{A. Perspective}

Pallet pooling is a typical kind of shaning economy. It is helpful to the development of green logistics. Most of literatures published so far are qualitative research on the operation modes and benefit analysis. It is worth noting that there are several scholars have shown their interest on information management, supply chain management, rental pricing, pallets allocation $\&$ tracking, quality control, sustainable development (carbon emissions) and so on. These topics are very important to pallet managers. Studies on those fields will become hot in the near future.

Almost all of the literatures on pallet pool information management are focused on tracking pallets and sharing information based on RFID and XML. There a re many new technologies as sensor technology, cloud computing, big data, etc. a re already implemented in other field besides pallet pooling. In order to a chieve the visual management of pallets and scientific decision-making, these technologies can also be studied in the use of pallet pool information management. 
Pallet pool supply chain management is a new research field in recent years. Scholars are focusing mainly on the research of supply chain design. In addition to the problem of supply chain design, there are many other problems in this complex system that should be researched. For example, partner selection and risk control. It is necessary to study on these topics according to the cha racteristic s of pallets.

Pallet allocation is vital to the pallet pool management. Most of the literatures on pallet allocation focused on allocation model and algorithm from the theoretical point of view, but there are inadequate data to support their results which severely affect the credibility and practicability. Furthermore, there is few literatures from the strategic view to study the influence of pallet allocation on decision-making. Therefore, the future research can be camied out in aspects of empincal and strategic research.

Pallets are perishable. So a reasonable pricing of pallet for a rental company can significantly promote its profits. However, most of the pallet rental companies are pricing pallets merely by negotiation with customers, which is lack of scientific pricing. Companies may lost the chances to get more revenue because of that. To price the rental pallet based on the theory of revenue management is therefore a pparently needed.

The problem of sustainable development is a hot issue that has been paid close attention by scholars. Pallet pooling can promote the sustainable development of economy and society. It is important to research on how to evaluate its impact on susta inable development and take more effective measures (such as the use of environmentally friendly materials, transportation, and processing methods) to reduce negative impact on the environment.

Sharing economy has penetrated into almost all areas of transportation, life services, health care, etc. In the field of logistics, as a typic al sharing economy mode, pallet pooling has been developed very well in the world. But compared with the smashing development of Uber and Airbnb, its development speed is way too slow. As mentioned above, "Intemet plus" is significant to sharing economy. The mode of "Intemet plus pallet pooling" is to greatly propel the development of pallet pooling.

\section{B. Suggestions on pallet pooling development in China}

The earliest pallet pool in China was operated by Chinese Railway Department. In 1965, the managers of Beijing Guanganmen railway station and Shanghai east station tried to exchange pallets. But the project was not successful. The reasons for the failure include: (1) The pallets' specification in China were varied, so it was hard to exchange pallets. (2) There was not an information system to manage the huge pool. (3) There were few professionals on pallet pooling. (4)The benefits of pallet pooling were not distinct, so the Chinese govemment did not pay much attention to that project.

Since 2003, there are more and more scholars and people with broad vision who appeal for the development of pallet pooling. Although attempts on development of pallet pools are being ca mied out, use of pallet pooling is not easy to succeed. We then suggest that:

(1) Apparently, the benefits of pallet pooling are significant. Especially for China during the transition period, the development of pallet pooling can greatly improve the speed and efficiency of goods circulation as well as reduce logistics costs and enhance the vitality of economic development. Chinese govemment should make a good planning for the development of pallet pooling.

(2) China has vast temitory and abundant resources. The development levels of each region various. For example, Beijing and Shanghai are developed regions, while Inner Mongolia and Tibet are developing regions. So each pallet pooling mode (rent, exchanging, and transfer of ownership) can find its room to be used in China. In fact, these common pallet pooling modes have been unable to meet the needs in China. Researchers have developed some new modes. For example, J ituowang is a pallet pooling website (http://jituowang.com/). Customers of this website can lend or rent pallets on this website. If a company has some idle pallets, it can post a message on the website to lend its pallets. If a company needs some pallets, it can post a message on the website to rent some pallets. By this website, those idle pallets dispersed in various locations in China can be used more effic iently. The companies who need pallets can make their needs met with lower cost. This kind of new pallet pooling mode is named as "Intemet plus pallet pooling".

(3) Pallet standardization is very crucial to the development of pallet pooling. The $1200 \mathrm{~mm} *$ $1000 \mathrm{~mm}$ pallets are suitable to be transported by trucks and trains, so Chinese govemment should promote the use of that standardization. 
(4) The construction of pallet pools contains a large variety of scientific problems, such as pallet pool supply chain management, pallets allocation, pallet rental pricing, information management, etc.. It is needed to do academic research in details according to the China's situation. Studying in this field also demands a large number of professionals, so the pallet pooling education is in urgent need.

(5) Chinese govemment should encourage enterprises to engage in the industry of pallet pooling. For instance, some enterprises should concentrate on developing pallet pooling information systems, and some pallet recyclers are needed to recycle empty pallets across the big country.

(6) The pallet pooling has been developed more than half a century. Chinese companies should leam the mature experience from the ones in United States, Australia, Japan, Korea and other developed countries. Given that China's political environment, geographical environment, economic development, social and culture are very different from other countries, Chinese companies should take these differences into consideration when they build their pallet pools.

\section{CONCLUSIONS}

Pallets are widely used in the world. Pallet pooling is a popular method of managing pallets. According to our analysis, there are many literatures on pallet pooling as to benefit analysis, mode choose, supply chain and information management, pallet allocation model and algorithm, rental pricing, quality control, sustainable development (carbon emissions), etc. We also have proposed that there are some topics should be studied in the nearfuture.

The development of China's pallet pool is quite late, but it has received high attention from the Chinese govemment. As an important innovation of the logistics industry, the development of pallet pool has been mentioned in both "The plan of logistic s industry restructuring and revitalization" and "The long-tem plan of logistic s industry development (2014 - 2020)". However, the construction of pallet pools is never an easy case. It is suggested that: (1) Chinese govemment should make a deliberate long-tem planning for the development of pallet pooling. (2) All the pallet pooling modes (rent, exchanging, and transfer of ownership) can be implemented in China. (3) Chinese govemment should promote the use of the $1200 \mathrm{~mm} * 1000 \mathrm{~mm}$ pallet. (4) It is demanded to take academic research into details according to the China's current situation. Education on fostering pallet pooling specialists is in urgent need. (5) Chinese govemment should encourage and offer necessary help to the enterprises to engage in the industry of pallet pooling. (6) Chinese enterprises should leam mature experiences from the developed countries. They need to take domestic situation into account when constructing their own pallet pools.

\section{ACKNOWLEDGMENT}

This paper was supported by the National Natural Science Foundation of China (71862026), Natural Science Foundation of Inner Mongolia (2018MS07006), China Postdoctoral Science Foundation (2018T110209), and China Scholarship Council Foundation (201808155025).

The authors are grateful to the anonymous referee for a careful checking of the details and for helpful comments that improved this paper.

\section{REFERENCES}

[1] Ren, J. W. (2012). Study on pallet allocation optimization over a pallet pool. Southwest J iaotong University, Chengdu, China.

[2] Ha mis, J. S., \& Worrell, J. S. (2008). Pallet management system: a study of the implementation of UID/RFID technology for tracking shipping materials within the department of defence distribution network. NAVAL Postgraduate School, Monterey, USA.

[3] Wu, Q. Y. (2013). Study on unit logistic: part one. Logistics \& Material Handling, 16(6): 108-111.

[4] Jiang, H., \& Lu L. (2001). Pallet pooling is helpful to logistic soperation. Logistic S \& Material Handling, 6(4): 9-12.

[5] Wu, Q. Y. (2003). Discussion on set up of china pallet pool system. Logistic s \& Material Handling, 8(12): 1-4.

[6] Sakai, K. J. (2003). Pallet pooling and environment. Logistics \& Material Handling, 8(6): 46-49.

[7] Auguston, K. A. (1991). Is the U.S. ready for pallet pooling. Modem Materia Is Handling, 46(8): 76.

[8] Don, M. (1996). What makes reusable packaging systems work. Logistic s Information Management, 9(4): $39-42$.

[9] Witt, C. E. (1999). Ec onomic of pallet rental. Material Handling Engineering, 54(9): 47-48.

[10] Raballand, G., \& Carroll, E. A. (2007). How do differing standards increase trade costs? The case of pallets. The World Economy, 30(4): 685-702.

[11] Meng, G. Q., \& Sun, K. Suggestions for China' pallet pooling. China Logistics \& Purcha sing, (23): 12-16.

[12] Li, T. P. (2006). Study on the problem of China logistics pallet exchange system and its counter measure. East China Economic Management, 20 (5): 58-98.

[13] Murray, J. (1967). Pallet pool is key to Swedish cargo handling efficiency. The J oumal of ICHCA, 3(3): 27-29. 


\section{Logistic s \& Susta ina ble Transport \\ Vol. 10, No. 1, J une 2019, 1-10 \\ doi: 10.2478/jlst-2019-0001}

[14] Brindley, C. (2010). Pallet math = profit\$ for all: experts study the economic fea sibility of an industry cooperative pool. Pallet Enterprise, (4): 22-26.

[15] Brindley, C. (2010). A look into china's expanding logistical framework and its path toward palletization. Pallet Enterprise, (11): 44-47.

[16] Brindley, C. (2014). Asian expansion: LOSCAM reveals key insights for Asian pallet market growth. Pallet Enterprise, (8): $18-22$.

[17] Ray, C. D., Michael, J. H., \& Scholnick, B. N. (2006). Supply-chain system costs of altemative grocery industry pallet systems. Forest Products J oumal, 56(10): 52-57.

[18] Roy, D., Camano, A. L., Pazour, J. A., \& Gupta, A. (2016). Cost-effective pallet management strategies. Transportation Research Part E, 93(9): 358-371.

[19] Lacefield, S. (2004). What's more "palatable"-renting or owning?. Logistic s Management, 43(4):63-66.

[20] Mosqueda, A. (2009). Pallet user education series: Red, white \& blue: a cost analysis of rental vs. white wood pallets. Pallet Enterprise, (7): 32-35, 38.

[21] Michel, R. (2014). Pallet Survey: How pallet trends stack up. Modem Materials Handling, (10): 30-34.

[22] Lai, Y. C. (2010). TPL plays a vital role in pallet pooling. China Logistics \& Purchasing, (18): 60-61.

[23] Yu, L. (2008). Research on the development policies and measures of railway pallets transport. Beijing Jiaotong University, Beijing, China.

[24] Wang, S. P., \& Gu, X. M. (2014). China pallet pool. China Business and Market, 28(9): 21-27.

[25] J in, S. S., Xiong, Q. X., Jiang, M. X., Wang, Y. L, \& Feng, D. Z (2008). Study on Chinese pallet pool Co.Ltd and its construction strategy. Industrial Engineering J oumal, 11(4): 19-23.

[26] Ge, H. Q. (2008). Study on the model and some related technical problems of Chinese pallet pool system. Zhejiang University of Technology, Hangzhou, China.

[27] Elia, V., \& Gnonl, M. G. (2015). Designing an effective closed loop system for pallet management. Intemational J oumal of Production Economics, 170 (12): 730-740.

[28] Xu, Q. (2010). Pallet pool supply chain management. China Business and Market, 24(3):22-25.

[29] Gnoni, M. G., \& Rollo, A. (2010). A scenario a nalysis for evaluating RFID investments in pallet management. Intemational J oumal of RF Technology Research, 2(1): 1-21.

[30] Zhang, Q. H., Wei, J., Cheng, G. Q., Wang, Z A., Yan, D. W., \& Zhao, S. S. (2009). Pallet rental information system based on RFID. In: Proceedings of 4th IEEE Conference on Industrial Electronics and Applications (pp. 886-891). New York, USA:IEEE.

[31] Kim, T., \& Glock, C. H. (2014). On the use of RFID in the management of reusable containers in closed-loop supply chains under stoc hastic container retum qua ntities. Transportation Research Part E: Logistics Transportation Research, 64(4): 1227.

[32] Chen, X. Z, Fu, P. H., \& Lv, G. F. (2009). Study on pallet rental system ba sed on RFID. China Logistic S \& Purc ha sing, (18): 70-71.

[33] Zhao, N. (2011). Quick response system for logistics pallets pooling service supply chain based on XML data sharing. Lecture Notes in Electrical Engineening, 98(2): 367-374.

[34] Li, J. B., He, S. W., Yin, W. C. (2018). The study of pallet pooling information platform based on cloud computing. Scientific Programming, 2018 (5):1-5.

[35] Ren, J. W., Chen, C. H., Xu, H., \& Zhao, Q. Q. (2018). An optimization model for the operations of a pallet pool with both radio-frequency identification-tagged pallets and non-tagged pallets. Advances in Mechanical Engineering, 10(1): 113.

[36] Brindley, C. (2011). Position is everything: rising transport costs make pallet logistics more critical for success. Pallet Enterprise, (6): 24-28.

[37] Doungpattra, N., Janupan, L, \& Ongkunaruk, P. (2012). Simulation for transport pallet cost reduction in pet food manufacturing: an empirical case study. Packaging Technology and Science, 25(6): 311-319.

[38] Ren, J. W., \& Zhang, X. Y. (2010). Pallet recovery model based on modified pallet pool system. Joumal of Southwest Jiaotong University, 45(3): 482-485.

[39] Ren, J. W., \& Zhang, X. Y. (2010). Pallet recovery stochastic programming model of pallet pool system. Control and Decision, 25(8):1211-1214.

[40] Ren, J. W., \& Zhang, X. Y. (2011). Two stage stochastic chance constrained programming model of pallet pool system dispatch. Control and Decision, 26(9):1353-1357.

[41] Ren, J. W. Zhang, X. Y. , Zhang, J., \& Ma, L. (2014). A multi-scenario model for pallets allocation over a pallet pool. Systems Engineering Theory \& Practice, 34(7):1788-1798.

[42] Zhou, K., He, S. W., Song, R., \& You, L. J. (2014). Optimization model of railway empty pallet dispatching based on the mode of pallet pool. J oumal of Beijing J ia otong University, 38(3): 22-26.

[43] Zhou, K., He, S. W., Song, R., \& You, L. J . (2015). Decision scheme optimization for empty pallets dispatching based on pallet pool mode. Control and Decision, 30(11): 2009-2013.

[44] Zhou, K., He, S. W., \& Song, R. (2016). Optimization for senvice routes of pallet senvice center based on the pallet pool mode. Computational Intelligence and Neuroscience, 2016(3):1-11.

[45] Ni, L, He, Y. D., Zhou, L. \& Deng, L (2015). Robust control optimization of triple-echelon closed-loop pallet pool system in multi-uncerta in environment. J oumal of Info mation and Computational Science, 12(7): 2635-2645.

[46] Ren, J.W, Lu, B., Wang, ZY. (2017). An optimization model for multi-type pallet allocation over a pallet pool. Advances in Mechanical Engineering, 9(5):1-9.

[47] Johnson, S. (1954). Optimal two-and-three stage production schedules with setup time include. Naval Research Logistics Qua rterly, 1(1): 61-68.

[48] Ji, Q. K., Hu, X. P., \& Sun, L. J . (2014). Empty container allocation: status and perspectives. Systems Engineering Theory \& Practice, 36(6): 1578-1586. 


\section{Logistic $s \&$ Susta ina ble Transp ort \\ Vol. 10, No. 1, J une 2019, 1-10 \\ doi: 10.2478/jlst-2019-0001}

[49] Baker, D. S. (2011). Proprietary pallets continue to plague recyclers, proposed Arizona law raises legal liability issue. Pallet Enterprise, (4): 38-45.

[50] Bilbao, A., Carrano A., Hewitt M., \& Thom B. (2011). On the environmental impacts of pallet management operations. Management Research Review, 34(11): 1222-1236.

[51] Carrano, A. L., Pazour, J. A., Roy, D., \& Thom, B. K. (2015). Selection of pallet management strategies based on carbon emissions impact. Intemational J oumal of Production Economics, 164 (6): 258-270.

[52] Bengtssona, J \& \& Logiea, J . (2015). Life cycle assessment of one-way and pooled pallet altematives. Procedia CIRP, 29: 414-419.

[53] Tomese, F., Camano, A. L, Thom, B. K., \& Pazour, J. A. (2016). Carbon footprint analysis of pallet remanufacturing. J oumal of Cleaner Production, 126 (7): 630-642.

[54] Tomese, F., Pazour, J. A., Thom, B. K., Roy, D., \& Camano, A. L.(2018). Investigating the environmental and economic impact of loading conditions and repositioning strategies for pallet pooling providers. Joumal of Cleaner Production, 172 (1):155-168

[55] Wu, Q. Y. (2013). Study on unit logistic s: part two. Logistics \& Material Handling. 18(7):104-106.

[56] Xu, Q. (2011). Collaborated Optimal Pricing Strategy of Pallets Pooling Supply Chain System. China Business and Market, 25(7): 54-59.

[57] Wu, J., Ren, J. W., \& Zhang, X. Y. (2015). Pallet rental pricing. Price: Theory and Practice, (11):162-164.

\section{AUTHORS}

A. Chunhua Chen, is a Phd Candidator at School of Business Administration, J iangxi University of Finance and Economics, Nanchang, China. She is also a VIP customer manager at Inner Mongolia Branch of Agric ultural Bank of China, Hohhot, China (e-mail: nmgchenchunhua@126.com).

B. J ianwei Ren, Phd, is an Associa te Professor at Transportation Institute, Inner Mongolia University, Hohhot, China, and a Postdoc at School of Mathematical Sciences, Inner Mongolia University, Hohhot, China. He is also an Ac ademic Visitor at Fa culty of Business, University of Plymouth, Plymouth, United Kingdom. (e-mail: renjianwei309@126.com).

C. Yunga A, Ms, is a VIP customer manager at Inner Mongolia Branch of Agricultural Bank of China, Hohhot, China (e-mail: nmgayunga@126.com).

Manuscript received by 29 J anuary 2019.

Published as submitted by the author(s). 